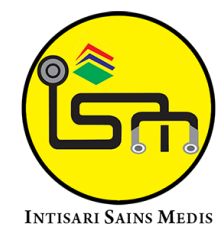

Published by Intisari Sains Medis

\title{
Immunopathogenesis of erythema nodosum leprosum
}

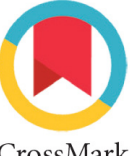

\author{
Made Sanitca Indah ${ }^{1 *}$, I Gusti Agung Ayu Dwi Karmila ${ }^{1}$
}

\section{ABSTRACT}

'Department of Dermatology and Venereology, Faculty of Medicine, Udayana University, Denpasar, Bali, Indonesia

\section{*Corresponding to:}

Made Sanitca Indah; Department of Dermatology and Venereology, Faculty of Medicine, Udayana University, Denpasar, Bali, Indonesia; made.sanitca@yahoo.co.id
Received: 2021-09-07

Accepted: 2021-12-03

Published: 2021-12-31
Leprosy is a chronic granulomatous disease. Its etiology is caused by Mycobacterium leprae (M. leprae). This disease may affect the skin, however it also may affect peripheral nervous system and other organs. The immunologic mechanism of erythema nodosum leprosum (ENL) has not been fully understood. The ENL reaction is the reaction of deposition in immune complex in the blood vessels. Recent studies have reported the association of several immunological markers with leprosy reactions, but inconsistent results

Keywords: eritema nodosum leprosum, immunology, immunopathogenesis, cytokine.

Cite This Article: Indah, M.S., Karmila, I.G.A.A.D. 2021. Immunopathogenesis of erythema nodosum leprosum. Intisari Sains Medis 12(3): 969-973. D0I: 10.15562/ism.v12i3.1134 have been obtained. Neutrophils are considered a histologic feature of ENL, histologic examination of ENL skin lesions revealed a strong perivascular neutrophil infiltrate throughout the dermis and subcutis. Another thing to note is T lymphocytes. It has been showed that the T-cell counts in peripheral blood of ENL patients is higher. Other immunological processes that play a role in EL immunopathogenesis involve T-helper (Th) cells, T regulatory cells, B cells, and other cytokines.

\section{INTRODUCTION}

Leprosy is a chronic granulomatous disease. It commonly affects the skin, peripheral nervous system and other organs. ${ }^{1}$ Transmission of leprosy occurs through close and prolonged contact through inhalation and droplets from patients infected with the bacillus $M$. leprae to susceptible individuals. Infection also occur through wound skin exposed to M. leprae. ${ }^{2}$

Leprosy reactions is classified into two, namely reversal reactions (type 1) and erythema nodosum leprosum (ENL), a type 2 reactions. ENL is the most common leprosy reaction. ${ }^{1}$ ENL often occurs in borderline leprosy and lepromatous type leprosy. ${ }^{3}$ ENL occurred in $1.2 \%$ of all cases of leprosy, $4.5 \%$ of multibacillary (MB) cases, and $15.4 \%$ of lepromatous leprosy (LL) cases. The hospital study showed that $13.7 \%$ of $\mathrm{MB}$ cases developed to ENL. ${ }^{4}$

ENL reactions can cause high morbidity and require appropriate treatment. This literature review discusses the causes of ENL and the factors that support the occurrence of ENL reactions to determine strategies for preventing and controlling inflammation that occurs.

\section{DEFINITION OF ERYTHEMA NODOSUM LEPROSUM}

Erythema nodosum leprosum (ENL) or type 2 leprosy reaction is an immunological complication of leprosy that causes inflammation of the skin, nerves, and other organs and is a type III hypersensitivity reaction (Coomb and Gell). It is a humoral immune response which is a reaction between $M$ antigens. leprae with antibodies (IgM, IgG) to form an antigen-antibody complex (Ag-Ab).,

\section{EPIDEMIOLOGY}

A retrospective study in Surabaya at 20152017, found that from 385 leprosy patients, $111(28.8 \%)$ patients developed ENL in 48 previously treated patients and 63 previously untreated patients. This study describes a relatively high prevalence of ENL, namely $28.8 \%$ in all leprosy patients and $33 \%$ of all $\mathrm{MB}$ cases in the leprosy division. A report showed a decrease in new cases of leprosy in Indonesia every year, which is 17,202 cases in $2015,16,826$ cases in 2016 , and 15,910 cases in $2017 .{ }^{7}$ The decrease in the number of visits could be due to a decrease in the number of new leprosy cases in Indonesia or the system New National Health that enforces vertical referrals based on health service level. ${ }^{8}$

\section{CLINICAL MANIFESTATION}

Clinical symptoms that often occur in ENL reactions are the emergence of painful erythematous nodules with a bilateral and symmetrical distribution, especially in the lower limbs, face, arms and thighs. The symptoms also can be found to be accompanied with systemic symptoms, including fever and malaise., ${ }^{3,9}$

Clinically, ENL reactions can occur in the form of mild or severe. It classified as mild if there are few erythematous nodules palpable with heat and pain, ulcers are rarely found, there are no constitutional symptoms (fever and joint 
pain), lymphadenopathy and oedema are not found in the body, no neuritis was found, there was no eye involvement and no other organ dysfunction. The clinical manifestation considered as severe if there are many erythematous hot and painful nodules, ulcers are often found, there are constitutional symptoms such as fever and joint pain, lymphadenopathy and oedema are often found in the legs, neuritis is found in one or several nerves, and may be accompanied by involvement eyes and other organ dysfunction (iridocyclitis, epididymo-orchitis) (Table 1). ${ }^{10-12}$ ENL reactions take 1-2 weeks, but many patients have multiple recurrences within 1 month. ENL can also be classified into 3 , they are acute ENL where there is only one episode of ENL for less than 24 weeks, recurrent ENL when one month after ENL treatment is completed the second/next ENL episode occurs and chronic ENL, which is ENL that occurs continuously for more than 24 weeks. ${ }^{6}$

Nodules in ENL may ulcerate, there is yellow pus containing degenerated acid- fast bacilli and polymorphic cells. Chronic ENL lesions show brownish induration on the legs and forearms. Deposits of immune complexes in blood vessels that can cause systemic vasculitis. ${ }^{9,11}$

\section{DIAGNOSIS CONFIRMATION}

To prevent nerve damage and morbidity, an early and accurate diagnosis is required. ${ }^{12}$ The diagnosis of ENL uses the diagnostic criteria of Naafs et al, in which the main criteria is needed and accompanied by 3 minor criteria for the diagnosis of ENL (Table 2). ${ }^{13}$

In The ENL reaction, leukocytosis is found $\left(20,000-50,000 / \mathrm{mm}^{3}\right)$ accompanied by an increase in the erythrocyte sedimentation rate (ESR) and the presence of C-reactive protein (CRP). Megaloblastic anemia could be found, also with mild elevation of serum bilirubin 1-2 m/100 $\mathrm{mL}$. Elevated serum transaminase [serum glutamate oxaloacetate transaminase (SGOT) and serum glutamic-pyruvic transaminase (SGPT)] indicates liver and muscle damage. ${ }^{13}$
Histological picture of ENL is characterized by oedema and mixed infiltration of inflammatory cells in the dermis and subcutis, especially neutrophils with eosinophils, lymphocytes, foamy macrophages aggregates, plasma cells and mast cells. In some cases, vasculitis and septal paniculitis and granular bacilli may be found in large size. ${ }^{11}$

\section{IMMUNOPATHOGENESIS}

Immunological markers of the ENL reaction include deposition of immune complexes, neutrophils, B cells, T cells, helper $\mathrm{T}$ cells $(\mathrm{Th})-17$, regulatory $\mathrm{T}$ cells (Treg), tumor necrosis factor (TNF)- $\alpha$ and other cytokines. A simplistic schema of the pathogenesis of ENL is presented in Figure 1.

\section{IMMUNE COMPLEX DEPOSITION}

The hallmark of autoimmune disease is the deposition of antigen-antibody complexes located at tissues or circulation. This

Table 1. Signs of ENL ${ }^{12}$

\begin{tabular}{lll} 
Signs & Mild Reaction & Severe Reaction \\
\hline Skin lesion & $\begin{array}{l}\text { Red nodules that feel hot and painful, can } \\
\text { become ulcers in small amounts }\end{array}$ & $\begin{array}{l}\text { Painful nodules on pressure can become deep ulcers, large in number } \\
\text { and the reaction lasts a long time }\end{array}$ \\
\hline Constitution & May or may not be accompanied by a mild fever & Mild to severe fever \\
\hline Peripheral nerve & No neuritis (tenderness or impaired function) & Accompanied by neuritis (tenderness and impaired function) \\
\hline Other organs & No impairment & $\begin{array}{l}\text { Inflammation of the organs of the body, including the eyes } \\
\text { (iridocyclitis), testes (epididymo-orchitis), kidneys (nephritis), } \\
\text { joints (arthritis), lymph nodes (lymphadenitis), disorders of the } \\
\text { bones, nose and throat. }\end{array}$ \\
\hline
\end{tabular}

Table 2. Diagnostic criteria of ENL ${ }^{13}$

\begin{tabular}{ll} 
Criteria & Clinical Manifestation \\
\hline Major & Eruption of erythematous papules, nodules or plaques that are diffuse and may be accompanied by ulceration \\
\hline Minor & - Mild fever \\
& - Nerve enlargement \\
& - Epididymo-orchitis \\
& - Arthritis \\
& - Lymphadenitis \\
& - Iridoxyclitis or episcleritis \\
& - Edema of the extremities or face \\
& - Loss of sensation or muscle strength \\
& - Ryrie or Ellis test positive
\end{tabular}




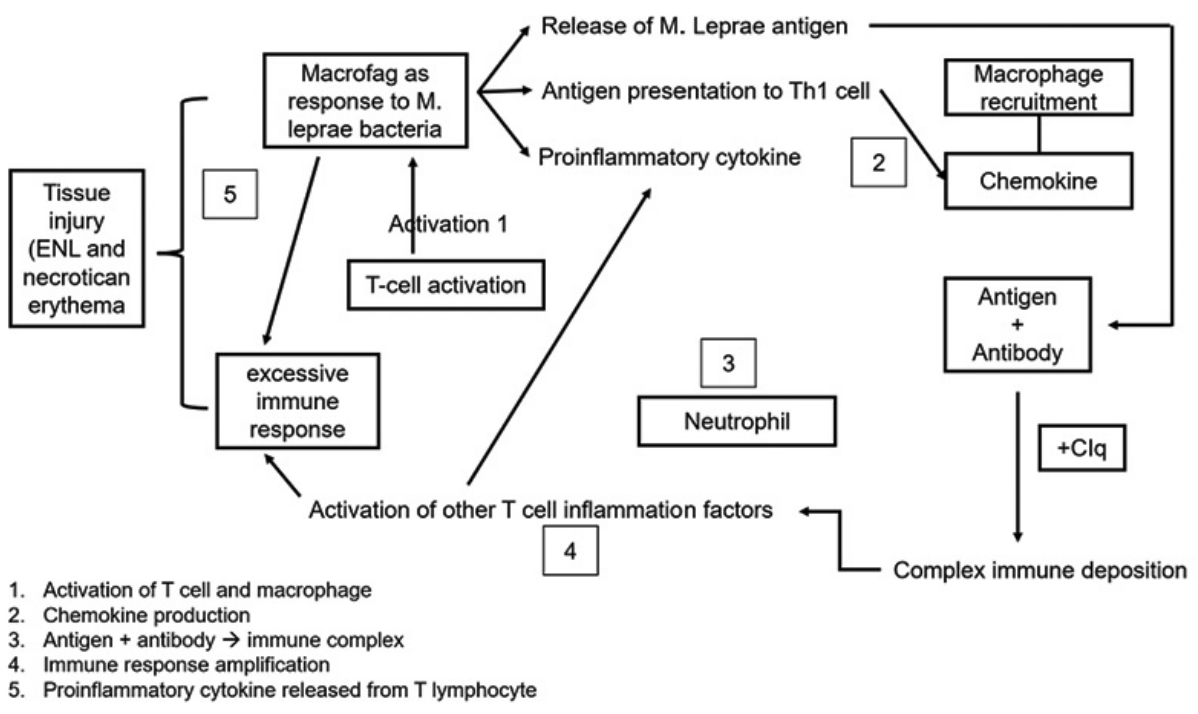

Figure 1. Schema of pathogenesis of ENL.?

includes systemic lupus erythematosus (SLE) and rheumatoid arthritis (RA). ${ }^{3}$ A study by Rojas et al found circulating immune complexes against phenolic glycolipid-1 (PGL-1) and the major cytosolic protein M. leprae (MCP-I). This finding supports the theory of immune complex, however similar complexes also found in leprosy controls, including in the BT cases, BL cases and LL cases. This finding suggested that immune complexes may not be specific process found in ENL. ${ }^{7}$ The pathogenesis mechanism must be proven by the finding of immune complex deposition in tissues, the interaction of the immune complex with the complement pathway, and the presence of bacterial antigens in the immune complex and phagocytic cells. These three components have not been elucidated in immune complex theory of ENL. ${ }^{14}$

\section{NEUTROPHIL}

Neutrophils is one cells types which also involved in the regulation of adaptive immunity. The neutrophils interact with lymphocytes, along with antigen presenting cells (APC). ${ }^{15}$ Neutrophils as cell motility, include E-selectin which is regulated by IL (interleukin)-1 $\beta$. In vitro activation of Toll-Like Receptor (TLR)-2 can induce IL- $1 \beta$. This molecule, along with interferon (IFN) $-\gamma$ resulted in stimulation of E-selectin expression and neutrophil attachment to endothelial cells. ${ }^{16}$

A study by Mabalay et al which performed skin biopsies of ENL lesions within 72 hours of onset showed a neutrophil predominance in $30.4 \%$ of the biopsies. The skin biopsies which performed between 9 and 12 days showed neutrophils in $1.6 \%$ of the specimens. They also found increased numbers of plasma cells, histiocytes and lymphocytes. ${ }^{17}$

The gene expression profile in ENL lesions consisted of an integrated pathway of neutrophil migration, TLR-2 activation, inflammatory reactions and $\mathrm{Fc}$ receptors $(\mathrm{FcR})$. The pathways involved including the induction of FcR or TLR 2 by IL- $1 \beta$, the activation of endothelial, and subsequent upregulation of E-selectin (CD62E) and neutrophil binding, and the last is the increased expression of inflammatory mediators. The study supports the administration of thalidomide, a very effective drug in the treatment of ENL. ${ }^{18}$

The surface receptor of neutrophils is CD64 ( Fc $\gamma \mathrm{RI})$. Its amount is decreased in resting neutrophils. However, its expression increased in conjunction with stressors (disseminated intravascular coagulation, infection of gram-negative bacteria, sepsis, and others). After starting the MDT, the intracellular components of $M$. leprae are released, which in turn upregulate the CD64. The increase expression of CD64 resulted in the increase of pro-inflammatory cytokines, subsequently involved in the mechanism of ENL. This mechanism explains the higher incidence of ENL after MDT initiation. $^{\text {? }}$

\section{T-Cell Lymphocyte}

Based on the type of $\mathrm{T}$ cell surface receptor molecule is divided into 2 , namely cluster of differentiation (CD)4 and CD8. CD4+ cells when activated will produce cytokines which are effector Th cells, while CD8+ lymphocytes form effector cytotoxic $\mathrm{T}$ lymphocytes (CTL). ${ }^{19} \mathrm{~A}$ study by Rao et al which observed the increase of $\mathrm{T}$ cells in LL patients, ENL and after ENL treatment showed the increase of T-Cells amount in ENL patients. The same results also obtained after ENL treatment compared to patients with LL. ${ }^{20}$

Bach et al reported an increase in CD4+ T-cell count, and CD4+/CD8+ ratio and a simultaneous decrease in blood CD8+ T-cell count in patients with ENL reactions compared with LL patients. ${ }^{21}$ Cooper et al visualized ENL reactions as decreased cytotoxic T-cell (CD8+) activity, which leads to a partial augmentation of Th (CD4) activity. This sufficient to produce antibodies and immunity, however not enough to clear the lesion from bacilli. ${ }^{22}$

\section{T helper (Th)-17}

In the process of functional classification of Th cells into Th-1/Th-2, Th- 1 cells will induce immune response which mediated by cells, leading to tissue damage. The Th-2 cells will induce allergic reactions. The mechanism of T-cell-mediated tissue damage cannot be fully elucidated only by the Th-1/Th-2 hypothesis. ${ }^{23} \mathrm{~T}$ helper-17 produces IL-17A, IL-17F and IL-22 which can cause inflammation and tissue damage, where this differentiation pathway influenced by various cytokines. ${ }^{24}$

Th-17 produces IL-17 which is considered a pro-inflammatory cytokine. The Th-17 resulted in the increment of nitric oxide, IL-1 $\beta$, IL- 6 , TNF- $\alpha$,IL-8 and various cell types. Th17 cells are the least studied T cells in leprosy. Only few studies demonstrated Th-17 involvement in the immunopathogenesis of ENL. ${ }^{25}$

TGF- $\beta$ and IL- 6 are pro-inflammatory cytokines that mediates Th-17 differentiation. In contrast to Treg cells, 
it inhibits the differentiation of Th-17 cell. $^{24,26}$

A study by Negera et al in 2017 found that patients with ENL had a significantly higher percentage of IL-17than control LL patients before treatment ( 26.45 vs $20.6 \%$, respectively, $p \leq 0.05 ; \mathrm{HL}=5.7)$.

\section{Regulatory T Cells (Treg)}

A study by Attia et al. investigated Treg cell levels in various clinical forms of leprosy patients in Egypt using flow cytometry. The conducted study found the lower value of percentage and absolute Treg in patients with ENL reactions (1.2\%) than patients with LL $(2.8 \%)$. The median Treg/T effector (Teff) was significantly lower in patients with ENL. ${ }^{27}$ Treg cells served to delay the proliferation and differentiation of naive CD4 cells. This mechanism resulted in the prevention of cytotoxic activity of CD8 T cells. The other effects caused is the suppression of the activation and production of B-cell antibodies. The overall result will limit the stimulatory capacity of antigen-presenting cells. Other molecules of CD80 and CD86 will also They be regulated. ${ }^{28}$

One study also reported the levels of IL17 , transforming growth factor (TGF) $-\beta$, IL-10 and Tregs in 43 leprosy patients and healthy controls. The highest percentage of Tregs was obtained in patients with TT leprosy (5.8\%) compared to LL (2.8\%) and ENL (1.15\%). ${ }^{29}$ Treg presentation and Treg/Teff ratio may play a role in LL type leprosy to remain stable or progress to an ENL reaction. The difference in the proportion of Tregs and Teff compared to the absolute number of Tregs and Teff can affect the course of the infection. ${ }^{30}$

\section{B CELLS}

Research on ENL immunopathogenesis via the $B$ cells pathway is still scarce in the literature. One study by Rao et al. in 1986 found an increase in the percentage and absolute number of $B$ cells in the serum of ENL patients. ${ }^{31}$ The B cells are considered as precursors to antibody-secreting plasma cells. This type of cells can also act as antigen presenting cells (APCs). They involved in the initiation and regulation of cell responses. ${ }^{32}$ The involvement of B cells in the mechanism of autoimmune disorders, e.g., rheumatoid arthritis (RA) and systemic lupus erythematosus (SLE) is in the revisited phase. The same also happen in the role of B-cells for pathogenesis of ENL. ${ }^{32}$

B cells are considered to not significantly involved in the pathogenesis of ENL. However, in the ENL, the increase of IgG1-secreting B cells was found, together with lower concentrations of $M$. lepraespecific IgG1 and IgG3.7 Mycobacterium leprae antigens, IgG antibodies, IgM, complement (C3d) and mRNA IL-4 were all identified in ENL skin lesions and IL-4 is known as a B cell stimulator. ${ }^{13}$

\section{Tumor Necrosis Factor (TNF)- $a$ and Other Cytokines}

A study involving 18 ENL patients with various stages of treatment with steroids or thalidomide found that serum TNF- $a$ levels varied from undetectable to very high levels. ${ }^{33}$ Barnes et al also reported TNF- release in ENL patients indicating that TNF- a can mediate immunopathological effects such as fever and tissue damage in ENL reactions. ${ }^{34} \mathrm{~A}$ study by Faber et al found an increase in TNF- in four of seven leprosy patients with reactions. ${ }^{35}$ The use of anti-TNF therapy with infliximab and etanercept in ENL patients can reduce inflammation, this proves the inflammatory role of TNF- $\alpha$ in ENL. ${ }^{35,36}$

Tumor necrosis factor- $\alpha$ is mainly produced by mononuclear phagocytic cells and $\mathrm{T}$ cells and is activated by antigens, NK cells and mast cells. Tumor necrosis factor- $\alpha$ is increased by interferon (IFN)- $\Upsilon$ induction and autocrine (autoregulatory) mechanisms. Tumor necrosis factor- $\alpha$ plays a role in inflammation (reaction episodes) and tissue and nerve damage (apoptotic induction). Serum TNF- a levels increase according to the severity of the leprosy reaction. ${ }^{33,37}$

Tumor necrosis factor- $\alpha$ cytokine is pro-inflammatory; for macrophage activation and the formation of granulomas, in preventing the expansion of mycobacterial infection. Tumor necrosis factor-a has a pleiotropic effect that can provide protective or detrimental effects based on the amount and time of its production, duration of exposure and the availability of other mediators in the cellular environment. ${ }^{38,39}$

The inflammatory response of ENL lesions caused by TNF- $a$ can occur directly by increasing the aggregation and attachment of polymorphonuclear leukocytes (PMN) or indirectly through endothelial stimulation by IL-1. Migration of PMNs to sites of inflammation is strongly associated with local chemoattractant concentrations and in situ expression of adhesion molecules. ${ }^{35,38}$

\section{CONCLUSION}

Leprosy reactions are acute or subacute inflammatory diseases mediated by immunological processes. The pathogenesis of ENL is the interaction of various factors with various inflammatory pathways. The pathogenesis of ENL is also mediated by $\mathrm{T}$ cells, TNF- $\alpha$ and other proinflammatory cytokines. Other pathogenesis is also still under investigation. The introduction of various immunological factors that play a role in the pathogenesis of ENL reactions can provide knowledge for us to choose the right therapy in ENL patients that will be useful to minimize the occurrence of disability.

\section{ETHICAL CONSIDERATION}

Ethical consideration was not appropriate for this review.

\section{AUTHOR CONTRIBUTION}

All authors have contributed equally in preparing this review article.

\section{CONFLICT OF INTEREST}

All authors declared no conflict of interest regarding the topic and publishing this article.

\section{FUNDING}

None.

\section{REFERENCES}

1. Costa PDSS, Fraga LR, Kowalski TW, Daxbacher ELR, Schuler-Faccini L, Vianna FSL. Erythema nodosum leprosum: update and challenges on the treatment of a neglected condition. Acta Trop. 2018;183:134-141.

2. Job CK, Jayakumar J, Kearney M, Gillis TP. Transmission of leprosy: a study of skin and 
nasal secretions of household contacts of leprosy patients using PCR. Am J Trop Med Hyg. 2008;78(3):518-521.

3. Polycarpou A, Walker SL, Lockwood DN. A systematic review of immunological studies of erythema nodosum leprosum. Front Immunol. 2017;8:233.

4. Voorend CGN, Pos EB. A systematic review on the epidemiological data of erythema nodosum leprosum, a type 2 leprosy reaction. PLOS Neglected Tropical Diseases. 2013;7(10): 1-10.

5. Prasetya HY, Rahmah ST, Muchtar SV. Management of Leprosy Reaction. Int J Dermatol Ven. 2012;1(3):24-34.

6. Costa PDSS, Fraga LR, Kowalski TW, Daxbacher ELR, Schuler-Faccini L, Vianna FSL. Erythema nodosum leprosum: update and challenges on the treatment of a neglected condition. Acta Trop. 2018;183:134-141.

7. Bhat RM, Vaidya TP. What is new in the pathogenesis and management of erythema nodosum leprosum. Indian Dermatology Online Journal. 2020;11(4):482-492.

8. Fransisca C, Zulkarnain I, Ervianti E, Damayanti, Sari M, Budiono, et al. A retrospective study: epidemiology, onset, and duration of erythema nodosum leprosum in Surabaya, Indonesia. Berkala Ilmu Kesehatan Kulit dan Kelamin - Periodical of Dermatology and Venereology. 2021;33(1).1-12.

9. Yap FB. Clinical characteristics predicting erythema nodosum leprosum (ENL) among patients with multibacillary leprosy (MBL) in Sarawak. Asian Pac J Trop Med. 2009;2:66- 70.

10. Suchonwanit $\mathrm{P}$, Triamchaisri S, Wittayakornrerk $S$, Rattanakaemakorn P. Leprosy reaction in Thai Population: A 20-year retrospective study. Dermatol Res Pract. 2015;2015:253154.

11. Salgado CG, Brito AC, Salgado UI, Spencer JS. Leprosy. In: Kang S, Amagai M, Bruckner AL, Enk AH, Margolis DJ, McMichael AJ, Orringer JS, editors. Fitzpatrick's Dermatology $9^{\text {th }}$ ed. New York: McGraw-Hill; 2019. p. 2892-924.

12. Kemenkes RI. Reaksi Kusta. Dalam: Pedoman Nasional Program Pengendalian Penyakit Kusta. Direktorat Jendral Pemberntasan Penyakit Menular dan Penyehatan Lingkungan. Jakarta: Kemenkes RI. 2012:111-22.

13. Kumar Kar H, Chauhan. Leprosy Reactions: Pathogenesis and Clinical Features. In: Kumar B, Kumar Kar H, editors. IAL Textbook of Leprosy. $2^{\text {nd }}$ Edition. New Delhi: The Health Sciences Publisher; 2017: 416-36.

14. Hoiby N, Doring G, Schiotz PO. The role of immune complexes in the pathogenesis of bacterial infections. Annu Rev Microbiol.
1986;40:29-53.

15. Leliefeld PH, Koenderman L, Pillay J. How neutrophils shape adaptive immune responses. Front Immunol. 2015; 6:471.

16. Prameswari R, Listiawan MY, Rosita C. Peran TNF- $\alpha$ pada imunopatogenesis ENL dan kontribusinya pada penatalaksanaan ENL. FK Unair. 2012; 24(1): 43-48.

17. Mabalay MC, Helwig EB, Tolentino JG, Binford $\mathrm{CH}$. The histopathology and histochemistry of erythema nodosum leprosum. Int J Lepr.1965; 33:28-49

18. Lee DJ, Li H, Ochoa MT, Tanaka M, Carbone RJ, Damoiseaux R, et al. Integrated pathways for neutrophil recruitment and inflammation in leprosy. J Infect Dis. 2010;201(4):558-569.

19. Kim HJ, Cantor H. CD4 T-cell subsets and tumor immunity: the helpful and the not-sohelpful. Cancer Immunol Res. 2014;2(2):91-98.

20. Rao TD, Rao PR. Enhanced cell-mediated immune responses in erythema nodosum leprosum reactions of leprosy. Int J Lepr Other Mycobact Dis.1987; 55(1):36-41.

21. Bach MA, Chatenoud L, Wallach D, Phan Dinh Tuy F, Cottenot F. Studies on T cell subsets and functions in leprosy. Clin Exp Immunol. 1981; 44(3):491-500.

22. Cooper CL, Mueller C, Sinchaisri TA, Pirmez C, Chan J, Kaplan G, et al. Analysis of naturally occurring delayed-type hypersensitivity reactions in leprosy by in situ hybridization. The Journal of experimental medicine. 1989;169(5):1565-1581.

23. Steinman L. A brief history of Th 17 , the first major revision in the Th 1/Th 2 hypothesis of $T$ cell-mediated tissue damage. Nature medicine. 2007;13(2):139-145.

24. Saini C, Siddiqui A, Ramesh V, Nath I. Leprosy reactions show increased Th17 cell activity and reduced FOXP3+ Tregs with concomitant decrease in TGF- $\beta$ and increase in IL-6. PLoS Negl Trop Dis. 2016;10(4):e0004592.

25. Negera E, Walker SL, Bobosha K, Howe R, Aseffa A, Dockrell HM, Lockwood DN. T-cell regulation in Erythema Nodosum Leprosum. PLoS Negl Trop Dis. 2017;11(10):e0006001.

26. Yang L, Anderson DE, Baecher-Allan C, Hastings WD, Bettelli E, Oukka M, et al. IL-21 and TGF-beta are required for differentiation of human T(H)17 cells. Nature.2008;454: 350352.

27. Attia EA, Abdallah M, Saad AA, Afifi A,Tabbakh $\mathrm{AE}$, Shennawy DE, et al. Circulating CD4+ $\mathrm{CD} 25$ high FoxP3 $+\mathrm{T}$ cells vary in different clinical forms of leprosy. Int $\mathrm{J}$ Dermatol. 2010;49:1152-1158.
28. Morgan MD, Day CJ, Piper KP, Khan N, Harper $\mathrm{L}$, Moss PA, et al. Patients with Wegener's granulomatosis demonstrate a relative deficiency and functional impairment of Tregulatory cells. Immunology. 2010;130(1):6473.

29. Abdallah M, Attia EA, Saad AA, Lotfi RA, Shennawy D E. Serum Th1/Th2 and macrophage lineage cytokines in leprosy; correlation with circulating CD4+ CD25high FoxP3+T-regs cells. Exp Dermatol. 2014;23:742-747.

30. Belkaid Y, Rouse BT. Natural regulatory T cells in infectious disease. Nat Immunol. 2005;6(4):353-360

31. Rao D, Rao PR. Enhanced cell-mediated immune responses in erythema nodosum leprosum reactions of leprosy. International Journal of Leprosy and Other Mycobacterial Diseases. 1987;55(1):36-41.

32. Martin F, Chan AC. B cell immunobiology in disease: evolving concepts from the clinic. Annu Rev Immunol. 2006;23(24):467-496.

33. Brenner D, Blaser H, Mak TW. Regulation of tumour necrosis factor signalling: live or let die. Nat Rev Immunol. 2015;15:362-374.

34. Barnes PF, Chatterjee D, Brennan PJ, Rea TH, Modlin RL. Tumor necrosis factor production in patients with leprosy. Infection and immunity. 1992;60(4):1441-1446.

35. Faber WR, Jensema AJ, Goldschmidt WF. Treatment of recurrent erythema nodosum leprosum with infliximab. $N$ Engl J Med. 2006;355:739-739.

36. Ramien ML, Wong A, Keystone JS. Severe refractory erythema nodosum leprosum successfully treated with the tumor necrosis factor inhibitor etanercept. Clin Infect Dis. 2011;52(5):e133-e135.

37. Sari N, Amiruddin MD, Amin S. Peran interleukin-2 (IL-2), interleukin-10 (IL-10), dan tumor necrosis factor- $\alpha$ (TNF- $\alpha$ ) pada penyakit kusta. MDVI. 2013;40(1):35-40.

38. Darmaputra IGN, Ganerwari PAD. Peran sitokin dalam kerusakan saraf pada penyakit kusta: Tinjauan Pustaka. Intisari Sains Medis. 2018;9(3):92-100.

39. Penna GO, MartelliCMT, Stefani MMA, Macedo VO, Maroja MDF, Chaul A. Thalidomide in the treatment of erythema nodosum leprosum (ENL): systematic review of clinical trials and prospects of new investigations. An Bras Dermatol. 2005;80(5):511-522.

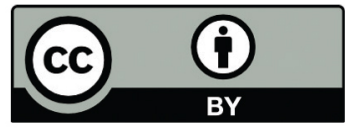

This work is licensed under a Creative Commons Attribution 